This is the peer reviewed version of the following article: Characterization Of Press And Solvent Extraction Oils From New Sunflower Seeds With Modified Phytosterol Compositions. Aída García-González, Joaquín Velasco, Leonardo Velasco, M. Victoria Ruiz-Méndez Journal of the Science of Food and Agriculture (2020), which has been published in final form at https://doi.org/10.1002/jsfa.10619. This article may be used for non-commercial purposes in accordance with Wiley Terms and Conditions for Self-Archiving.

\title{
CHARACTERIZATION OF PRESS AND SOLVENT EXTRACTION OILS FROM NEW SUNFLOWER SEEDS WITH MODIFIED PHYTOSTEROL COMPOSITIONS
}

RUNNING TITLE: Sunflower oils with modified phytosterol compositions

Aída García-González, ${ }^{1}$ Joaquín Velasco, ${ }^{1}$ Leonardo Velasco ${ }^{2}$ and M. Victoria Ruiz-Méndez ${ }^{1 *}$

${ }^{1}$ Instituto de la Grasa, Consejo Superior de Investigaciones Científicas (CSIC), Campus/Building 46, Ctra. de Utrera km 1, E-41013 Sevilla, Spain

${ }^{2}$ Instituto de Agricultura Sostenible, Consejo Superior de Investigaciones Científicas (CSIC), Alameda del Obispo s/n, E-14004 Córdoba, Spain

*To whom correspondence should be addressed:

Telephone: $\quad+34954611550$

Fax: $\quad+34954616790$

E-mail: mvruiz@ig.csic.es

ORCID: García-González A, http://orcid.org/0000-0002-2567-9916; Velasco J, http://orcid.org/0000-0003-4206-3037; Velasco L, http://orcid.org/0000-0003-4998-9406; RuizMéndez M V, http://orcid.org/0000-0003-0750-7915 


\section{ABSTRACT}

BACKGROUND: Phytosterols are plant components with health benefits. Oleaginous seed hybridization can be relevant to increase phytosterols in diet through enriched oils. Sunflower oils obtained by press (PO) and subsequent solvent extraction (SO) from three types of phytosterol-enriched seeds were characterized. One presented a phytosterol composition of common sunflower seeds, whereas the others were rich in Campesterol and 47 -Estigmastenol, respectively. Seeds from two different harvests, 2015 and 2017, were studied.

RESULTS: The type of extraction did not have a significant influence on the fatty acid (FA) composition. However, considerable differences were found between harvests. The oleic-tolinoleic ratio decreased from 0.71 in 2015 to 0.47 in 2017. The phytosterol compositions of the PO were similar to their SO homologues and no substantial differences were found between harvests. However, the SO presented higher total contents of phytosterols (4849-9249 $\mathrm{mg} \mathrm{kg}^{-1}$ ) than the PO (2839-5284 $\mathrm{mg} \mathrm{kg}^{-1}$ ) and the oils of 2017 showed higher levels (4476-9249 $\mathrm{mg} \mathrm{kg}^{-}$ $\left.{ }^{1}\right)$ compared to $2015\left(2839-5754 \mathrm{mg} \mathrm{kg}^{-1}\right)$. Unlike phytosterols, no significant differences were found in the tocopherol contents between the PO and SO or between harvests. The PO met Codex specifications for edible oils, except for trace metals, with concentrations close or above the limits for $\mathrm{Cu}, \mathrm{Fe}, \mathrm{Pb}$ and $\mathrm{As}$.

CONCLUSION: Differences in environmental and/or cultivation conditions between harvests may result in substantial differences in the FA composition and phytosterol content in oils from the new sunflower seeds. Rigorous measures and controls to avoid metal-trace contamination are required so that the $\mathrm{PO}$ can be considered edible virgin oils.

Keywords: phytosterols; sunflower oil; press oil; solvent-extracted oil; virgin oil; heavy metals 


\section{INTRODUCTION}

Today, consumers are increasingly demanding foods enriched in bioactives to improve health and reduce risk factors associated with ailments. Phytosterols are bioactive components present in plants with different health benefits, such as their ability to reduce cholesterol in plasma. There are numerous foods in the market that have been enriched in phytosterols by simple addition. $^{1}$

Vegetable oils are principal sources of phytosterols. ${ }^{2}$ Oleaginous seed hybridization can be a relevant alternative to increase phytosterols in diet through oils enriched in a natural way. In fact, new sunflower seed lines with increased phytosterol content and modified phytosterol compositions have recently been developed. ${ }^{3,4}$ An in-depth study of extraction and composition of the oils from these new seeds is required to examine their feasibility in market.

The industrial production of sunflower oils is carried out by press followed by subsequent solvent extraction. In general, both oils are blended and the resulting oil is refined for commercialization. However, the great interest of consumers for minimally processed foods makes it appealing to consider the two oils separately so that the press oils can be commercialized as non-refined or virgin oils. ${ }^{5}$

The production of virgin oils from new cultivars with modified phytosterol contents would provide higher quality oils, since part of the compounds of nutritional interest, such as phytosterols, are lost in the refining process. ${ }^{6}$ The Codex Alimentarius ${ }^{7}$ classifies virgin oils as those that are obtained by mechanical procedures without modifying the oil and by application of heat only, without applying refining. The elements $\mathrm{Ca}, \mathrm{Mg}, \mathrm{Cu}, \mathrm{Mn}, \mathrm{Fe}, \mathrm{Zn}, \mathrm{Co}, \mathrm{Mo}$, Se and I are regarded as important trace elements from a nutritional point of view, whereas $\mathrm{Cd}$ and $\mathrm{Pb}$, incorporated by environmental pollution, ${ }^{8}$ are considered highly toxic and their levels are limited by Codex specifications. ${ }^{7}$

The influence of the oil extraction procedures separately, press followed by subsequent solvent extraction, on the chemical composition of oils from three types of sunflower seeds obtained from hybrids enriched in phytosterols were studied. ${ }^{3}$ The phytosterol composition of one of them was that found in common sunflower seeds, whereas the other two presented high concentrations of Campesterol (CAMP) and $\Delta 7$-Estigmastenol ( $\Delta 7$-STIG), respectively. Seeds from two different harvests, 2015 and 2017, were evaluated. The results of the press oils were compared to the Codex specifications for edible virgin oils. 


\section{MATERIALS AND METHODS}

\section{Seeds}

The seeds were provided by the Institute for Sustainable Agriculture (CSIC) (Córdoba, Spain). They were developed by Fernández-Cuesta et $a^{3}$ using recombination of seeds from germplasm. The seeds with conventional phytosterol composition had been used as a control sample in the genetic studies and it was also considered as such in the present work, since their total content of phytosterols was within the range established for non-modified sunflower seeds. $^{7}$

The two harvests examined were different in terms of sowing time. The sowing of 2015 took place on March $27^{\text {th }}$. The flowering occurred on June $2^{\text {nd }}$, with $50 \%$ of the plants in bloom, while ripening took place on July $17^{\text {th }}$, taking into account that $50 \%$ of the plants were ripen. In 2017, planting was later, on April $13^{\text {th }}$. Flowering occurred on June $6^{\text {th }}$ and ripening on July $15^{\text {th }}$.

\section{Extraction processes}

Sunflower seeds were subjected to press followed by solvent extraction. The oil extraction processes were replicated in selected samples. The CAMP sample of 2015 was divided into two portions and $\Delta 7$-STIG of the same crop in three. The oils obtained from each portion were treated as independent samples. Previous to the extraction, $10 \%(\mathrm{w} / \mathrm{w})$ distilled water was added to the seeds and then these were conditioned in an oven at $60^{\circ} \mathrm{C}$ for $1 \mathrm{~h}$.

Extraction by press (Expeller). The device used was a 40a Täby Pressen (Skeppsta Maskin AB, Örebro, Sweden) with a capacity of $3.5 \mathrm{~kg} \mathrm{~h}^{-1}$. The Expeller comprised a 12-mm nozzle (i.d.) and operated with a screw rotation speed of $70 \mathrm{rpm}$. The amounts of seeds processed in 2015 were $1 \mathrm{~kg}$ control, $3 \mathrm{~kg}$ CAMP and $5 \mathrm{~kg}$ 47-STIG, whereas those in 2017 were $13 \mathrm{~kg}$ control, 3 kg CAMP and $5 \mathrm{~kg} \Delta 7$-STIG.

Solvent extraction. The residual oil in collets was further extracted in a Soxhlet (2-kg capacity). An amount of 1 or $2 \mathrm{~kg}$ pellets and $2.5 \mathrm{~L}$ hexane were used in each extraction. This was performed for $6 \mathrm{~h}$. The solvent was removed in a rotary evaporator at $60^{\circ} \mathrm{C}$ under vacuum.

For comparative purposes, the total oil obtained by direct Soxhlet extraction of ground seeds was also evaluated. The extraction was performed in a Soxhlet (250-g capacity) for $4 \mathrm{~h}$ according to UNE-EN ISO 659:2010. An amount of 10-15 g ground seeds and 150 mL hexane were used. 


\section{Analytical methods}

The moisture in the seeds was determined according to official method UNE-EN ISO 665:2001. The total content of oil was performed with hexane according to UNE-EN ISO 659:2010. Acidity was determined following method UNE-EN ISO 660:2010.

The FA composition and the levels of phytosterols were determined by using a recent method developed in our lab. ${ }^{9}$ Briefly, an aliquot of $50-\mathrm{mg}$ oil was trans-methylated with $5 \mathrm{~mL}$ of $3 \%$ sodium methoxide solution in methanol at $80^{\circ} \mathrm{C}$ for $30 \mathrm{~min}$. Then for the methylation of the free FA, a solution of $4 \%$ sulfuric acid in methanol was added and the reaction was run at $80^{\circ} \mathrm{C}$ for 30 min. The lipid fraction was extracted three times with n-hexane, washed two times with water and dried with anhydrous sodium sulfate. Finally, the solvent was evaporated under nitrogen and the sample was re-dissolved in hexane for SPE fractionation $\left(\mathrm{NH}_{2}-500 \mathrm{mg} / 3 \mathrm{~mL}\right)$. Two fractions comprising the FA methyl esters and the phytosterols, respectively, were obtained and analyzed by GC. ${ }^{9}$

Tocopherols were determined by HPLC with fluorescence detection following IUPAC Standard Method 2.432.

The analysis of metal and non-metal traces, i.e. $\mathrm{Al}, \mathrm{As}, \mathrm{B}, \mathrm{Ba}, \mathrm{Ca}, \mathrm{Cd}, \mathrm{Co}, \mathrm{Cr}, \mathrm{Cu}, \mathrm{Fe}, \mathrm{K}, \mathrm{Mg}$, $\mathrm{Mn}, \mathrm{Na}, \mathrm{Ni}, \mathrm{P}, \mathrm{Pb}, \mathrm{S}, \mathrm{Sr}, \mathrm{V}$ and $\mathrm{Zn}$, were determined by Inductively Coupled Plasma-Optical Emission Spectrometry (ICP-OES) at the Institute of Natural Resources and Agrobiology (CSIC) (Seville, Spain). SRM 1573a (Tomato Leaves) and an inter-laboratory sample (SE 2016 IPE-WEPAL) from the University of Wageningen were used as reference materials. Briefly, an aliquot of $0.25 \mathrm{~g}$ of each oil sample, weighed with an accuracy of $0.1 \mathrm{mg}$, was digested with a mixture of $4 \mathrm{~mL}$ of nitric acid and $2 \mathrm{~mL}$ of hydrogen peroxide in hermetically sealed Teflon vessels in a microwave oven (MILESTONE mod. START D). The digested sample was dissolved in $25 \mathrm{~mL}$ of purified water and filtered for further analysis. The measurements were performed on a Varian ICP 720-ES axial configuration device.

\section{Statistical analyses}

A full factorial design of three factors, type of seed (Control, GF-2 and GF-7), harvest (2015 and 2017) and extraction process (press, solvent extraction of the oil remaining after press and solvent extraction of total oil) was considered. The statistical program used was SPSS version 24.0 (SPSS Inc., Chicago, IL, USA) and significance was considered at $p<0.05$.

Univariate analysis using a generalized linear model (GLM) was applied to assess the influence of the type of seed and harvest on the moisture content of seeds and oil yield. Student's t-test was used for comparison between the crops. Analysis of variance (ANOVA) and Tukey's test were applied for comparison between the three types of seeds. 
For the FA composition data, a GLM was used applying multivariate analysis of three factors. The type of seeds, harvest and extraction process were the independent factors, while the dependent variables were each of the FAs. The acids C16:1, C18:3 and C20:1 were not taken into account, since their quantities were so low that in certain samples they could not be determined for presenting levels below the quantification limits. Levene's test was not met for any of the FAs $(p=0.000)$ and, therefore, non-parametric analysis for independent samples was applied to each of the three factors. The significance tests applied were the Kruskal-Wallis and Mann-Whitney $U$ tests for 3 and 2 levels, respectively. Because substantial differences between harvests were found, the same non-parametric analysis was applied to the data obtained for each crop separately. The comparison between crops was carried out by applying the paired-samples $T$-test and also a non-parametric test of related samples. Both tests provided equal results.

The same statistical analysis described above for the FAs was used for the composition of phytosterols, but, for obvious reasons, the statistical analysis was applied separately to each type of sample (Control, CAMP and $\Delta 7$-STIG). Again, Levene's test was not fulfilled. Nonparametric analysis for independent samples was applied to evaluate the influence of the extraction process, whereas a non-parametric analysis of related samples was used to assess the influence of the harvest year.

The total phytosterols content was analysed using a three-factor GLM. Again, it was necessary to apply non-parametric tests because Levene's test was not met. Non-parametric analysis of independent samples was used to evaluate the influence of the type of seeds and the extraction process, whereas non-parametric analysis of related samples was applied to evaluate the harvest year. Due to the large differences found between crops, the statistical analysis was applied to data of each crop separately. To establish differences between the average values of oils obtained by different extraction processes, for each type of seeds and year of harvest, one-factor ANOVA was used applying Tukey's test for equal variances or Games-Howell for unequal variances.

The tocopherol contents and the metal trace contents were analysed with the paired-samples $T$ test to assess the influence of the extraction process (press and solvent) and the harvest (2015 and 2017). ANOVA and Tukey's test were used to compare the three types of seeds. 


\section{RESULTS AND DISCUSSION}

\section{Characteristics of the seeds}

The seed samples presented moisture contents that were between 45 and $67 \mathrm{~g} \mathrm{~kg}^{-1}$ (Table 1). These values were similar to those found in the literature. ${ }^{10}$

The press extraction gave rise to yield values that were between 213 and $312 \mathrm{~g} \mathrm{~kg}^{-1}$, expressed on seed weight (Table 1). Slightly higher values were obtained for the $\Delta 7$-STIG samples, with average of approximately 300 against 230 and $250 \mathrm{~g} \mathrm{~kg}^{-1}$ obtained in the Control and CAMP, respectively. According to Gunstone, ${ }^{11}$ the mechanical extraction of sunflower oil can reach yields between 700 and $800 \mathrm{~g} \mathrm{~kg}^{-1}$ of total oil. In the present study, the hybrids CAMP and $\Delta 7-$ STIG presented values between 710 and $730 \mathrm{~g} \mathrm{~kg}^{-1}$ of total oil. No significant differences were found for the press performance between the two harvesting periods.

The amounts of oil obtained by solvent extraction in the resulting pellets were similar for the Control and $\triangle 7$-STIG samples, with average values of $160 \mathrm{~g} \mathrm{~kg}^{-1}$, and slightly lower for the CAMP sample, with $130 \mathrm{~g} \mathrm{~kg}^{-1}$.

With respect to the mass balance, the total amount of oil obtained in the two extraction procedures as a whole was consistent with the total oil content in the seeds. In fact, the meal residual oil was very low, ranging between 1.2 and $3.0 \mathrm{~g} \mathrm{~kg}^{-1}$, which corresponded to $2-5 \mathrm{~g} \mathrm{~kg}^{-1}$ of the total oil extracted.

\section{Acidity}

Acidity did not exceed $2 \%$ in all cases (Table 1S). The oils obtained by press (PO) showed lower values $(\leq 1 \%)$ compared to the oils obtained by solvent extraction (SO) $(0.7-1.6 \%)$. The results for the PO were in agreement with previous studies. ${ }^{12,13}$ In this regard, Bendini et al. ${ }^{13}$ analyzed regular cold-pressed sunflower oils manufactured by different European countries and found acidity values of $0.65-1.59 \%$, figures that are characteristic of virgin oils (unrefined) of good quality.

\section{Fatty acid composition}

The analysis of FAs for the three hybrids showed similar compositions and characteristic of conventional high linoleic sunflower oils (Table 2). As expected, C18:1 and C18:2 constituted $87-89 \%$ of all FAs, which was consistent with CODEX standards. ${ }^{7}$

No significant differences were found in the composition of fatty acids between the PO and SO. Nor were significant differences found when the oils obtained by the three extraction procedures were compared, press, solvent extraction of the remaining oil after press and solvent extraction 
of total oil. Therefore, the results showed that the extraction processes did not have a significant influence on the fatty acid composition.

However, substantial differences were found between oils from different seasons. The C18:1 content was higher for the 2015 oils, with an average of $36.6 \%$ ( \pm 2.6$)$ compared to $28.1 \%$ ( \pm $3.2)$ in 2017. The opposite occurred for the C18:2, with an average of $51.8 \%( \pm 2.8)$ in 2015 compared to $60.2 \%( \pm 2.7)$ in 2017. Since the harvest factor presented a high variability, statistical analysis was applied to the data of each harvest separately. The results of this analysis showed slight differences for all FAs when the three oil samples were compared in both the 2015 and 2017 harvests. Again, no substantial differences were found when the extraction methods were compared in each season separately. Only slight but significant $(p<0.05)$ differences were observed and these were sample and harvest dependent (Table 2).

The substantial differences found between oils from different harvesting periods could be related to differences in environmental conditions during seed development. Differences in temperature and water stress can have consequences in the physiological accumulation of FAs. ${ }^{14-17}$ According to Lajara et al. ${ }^{14}$ the average temperature from flowering to ripening seems to be an important factor that affects the FA composition of sunflower oil. They observed that an increase in temperature resulted in a decrease of linoleic acid and an increase of oleic acid. The effect of these factors, however, seemed to depend on the type of genotype studied, i.e. sunflower versus high oleic sunflower. In high oleic sunflower oils, only temperature affected the oleic-to-linoleic ratio. ${ }^{15}$

In the present study, temperatures were recorded during the two growth periods. The 2017 harvest was exposed to higher temperatures, with an average of $29.0^{\circ} \mathrm{C}$ compared to $27.5^{\circ} \mathrm{C}$ in 2015. The maximum temperature was also higher, $37.7^{\circ} \mathrm{C}$ compared to $36.6^{\circ} \mathrm{C}$, and especially the minimum temperatures, $20.0^{\circ} \mathrm{C}$ versus $17.4^{\circ} \mathrm{C}$. Figure 1 shows the distribution of the temperatures recorded during the growing cycle. The main differences took place in the initial period, where temperatures in 2017 were significantly higher. However, unlike other studies, ${ }^{15}$ the oleic-to-linoleic ratio decreased markedly in the 2017 harvest, from 0.71 in 2015 to 0.47.

Differences in rainfall between the harvests were also observed. Although there were no substantial changes in the total amount between 2015 (0.47 $\left.\mathrm{mm} \mathrm{day}^{-1}\right)$ and 2017 (0.48 mm day ${ }^{1}$ ), there were differences in the distribution over time (Figure 1). Rainfall was less numerous in 2017. These differences could have had an impact on the FA composition and have contributed differently in different stages of seed development. In this regard, Roche et al. ${ }^{17}$ observed in safflower seeds that a decrease in rainfall resulted in a decrease in C18:2 level, while no significant differences were observed in C18:1 level. 


\section{Phytosterols}

As remarked earlier, the Control sample presented a phytosterol composition similar to that of conventional or non-modified sunflower seeds (Table 3). Fernández-Cuesta et al. ${ }^{18}$ reported values of $54.0-60.6 \%$ for $\beta$-Sitosterol, $13.3-19.1 \%$ for $\Delta 7$-Stigmastenol, $7.9-10.9 \%$ for Campesterol, $9.0-10.5 \%$ for Stigmasterol and $2.8-4.2 \%$ for $\Delta 7$-Avenasterol.

The CAMP sample presented 27.9\% $( \pm 2.5)$ of Campesterol versus $7.2 \%( \pm 0.7)$ found on average in the other two samples (Table 3 ). The $\Delta 7$-STIG sample showed $26.4 \%( \pm 2.4)$ of $\Delta 7$ Stigmastenol versus $7.4 \%( \pm 0.6)$ and $16.6 \%( \pm 1.7)$ found in the CAMP and Control samples, respectively. The increase in the levels of these two types of phytosterols in the seeds resulted in a decrease in the levels of the majority sterol, $\beta$-Sitosterol. While the average level of $\beta$ Sitosterol in the Control was $62.2 \%( \pm 2.2)$, the relative amounts found in CAMP and $\Delta 7$-STIG were $49.7 \%( \pm 1.1)$ and $51.0 \%( \pm 2.5)$, respectively.

As in previous studies, ${ }^{12}$ no substantial differences were found in the composition of phytosterols between the PO and SO. Only, slight differences were observed and these were both sample and harvest dependent (Table 3). Likewise, slight but significant $(p<0.05)$ differences were also found in the phytosterol compositions between oils from different harvests. These were sample dependent except for stigmasterol, whose levels were greater for 2017.

Regarding the total content of phytosterols, the $\Delta 7$-STIG sample showed higher concentrations than the Control and CAMP samples, whereas no significant differences were found between the last two samples, neither for the 2015 harvest $(p=0.443)$ nor for that of $2017(p=0.912)$ (Table 3).

The SO showed higher total phytosterol contents (4849-9249 $\mathrm{mg} \mathrm{kg}^{-1}$ ) than their PO homologues (2839-5284 mg kg${ }^{-1}$ ). These results are in agreement with previous studies on sunflower seeds ${ }^{3,12}$ and also in other oleaginous seeds. ${ }^{19}$ The higher concentrations of phytosterols in the SO can be attributed to the higher extractive capacity of the solvent, despite its lower polarity compared to the oil. In the PO, the concentration of phytosterols depends on the amount of oil released, which acts as a solvent. Once the oil is saturated in phytosterols, this cannot incorporate more amount. However, from a material that has already lost a large amount of oil in the previous press extraction, the phytosterols are concentrated in the solvent extraction by continuous contact with fresh solvent.

No significant differences were found in the total content of phytosterols between the PO and the total oils, neither in the 2015 harvest $(p=0.111)$ nor in $2017(p=0.406)$. Even when the phytosterol contents were higher in the SO, their contribution to the total oil was not sufficient 
to significantly increase the levels of the PO. In addition, the oil that would result from the blend between the PO and SO must be refined, giving rise to partial losses of phytosterols. ${ }^{6}$ Therefore, cold press oils are a good alternative to the oils obtained from the mixture in terms of the total content of phytosterols.

The oils of the 2017 harvest clearly showed higher total contents of phytosterols than those of 2015. The concentrations found for the PO were between 2839 and $4290 \mathrm{mg} \mathrm{kg}^{-1}$ in 2015 and between 4476 and $5284 \mathrm{mg} \mathrm{kg}^{-1}$ in 2017. Likewise, the concentrations in the SO were between 4849 and $5754 \mathrm{mg} \mathrm{kg}^{-1}$ and between 6678 and $9249 \mathrm{mg} \mathrm{kg}^{-1}$ in 2015 and 2017, respectively. These remarkable differences could also be attributed to differences in environmental conditions during seed development. The higher temperatures recorded in 2017, in combination with the differences remarked above for the rainfall, may explain the greater concentrations of total phytosterols in the oils of this harvest. In this regard, Schaller ${ }^{20}$ suggested that a greater accumulation of phytosterols in sunflower seeds may be a response of the seeds to high temperatures, due to their role in regulating fluidity and permeability of the cell membranes. Later, Roche et al..$^{14}$ observed that high levels of phytosterols were related to warm temperatures and severe water deficits. In another study, Roche et al. ${ }^{21}$ stated that higher levels of total phytosterols were obtained with planting late, with higher average temperatures being recorded during flowering and seed maturation. These results are also in agreement with other studies on safflower seeds ${ }^{17}$ and on soybeans subjected to high temperatures in greenhouse ${ }^{22}$ and also in the field. ${ }^{23}$ In contrast, no temperature effect has been observed in canola seed. ${ }^{24}$ In addition, different authors have reported that water stress during seed development improves the accumulation of phytosterols in sunflower seeds. ${ }^{25}$

\section{Tocopherols}

Both the composition and contents of tocopherols found in the oils were characteristic of conventional sunflower oils. In agreement with reported data, the oils comprised $\alpha$-tocopherol (96\% of total tocopherols) and minor amounts of $\beta$-tocopherol. ${ }^{26}$ The CAMP oils exhibited the highest levels of tocopherols (922 $\left.\pm 71 \mathrm{mg} \mathrm{kg}^{-1}\right)$, followed by $\Delta 7$-STIG oils $\left(762 \pm 28 \mathrm{mg} \mathrm{kg}^{-1}\right.$ ) and the Control sample $\left(512 \pm 14 \mathrm{mg} \mathrm{kg}^{-1}\right)$ (Table $\left.2 \mathrm{~S}\right)$. The total tocopherol contents were in the range reported in other studies. ${ }^{27}$ The results obtained in the PO were similar to their SO counterparts. Unlike the total content of phytosterols, no significant differences in the total content of tocopherols were found between oils from the two harvests studied.

Studies on soybean ${ }^{28}$ and sunflower ${ }^{18,26}$ oils have clearly shown that tocopherol levels depended on genotype and weather conditions, in particular, temperature. A reduction in the total content of tocopherols took place when the plants were exposed to higher temperatures during the seed development. ${ }^{26}$ The results of the present study are however in agreement with studies on 
soybean, where the total levels of tocopherols were not affected by different temperatures during the seed growth. ${ }^{29}$

\section{Heavy metals and other elements}

Table 4 shows the contents of heavy metals and other elements found in the oils. The major elements were $\mathrm{Ca}, \mathrm{Fe}, \mathrm{K}, \mathrm{Mg}, \mathrm{Na}, \mathrm{P}$ and $\mathrm{S}$. The levels of $\mathrm{Cu}$ and $\mathrm{Fe}$ were consistent with those found in other studies, ${ }^{30}$ but $\mathrm{Cd}, \mathrm{Pb}$ and $\mathrm{Zn}$ levels were below those reported by Ansari et al., ${ }^{31}$ whose ranges were $1.7-6.2 \mathrm{mg} \mathrm{kg}^{-1}, 0.7-4.4 \mathrm{mg} \mathrm{kg}^{-1}$ and $2.7-7.7 \mathrm{mg} \mathrm{kg}^{-1}$, respectively.

Significant differences in the contents of $\mathrm{Ca}, \mathrm{K}, \mathrm{Mg}$ and $\mathrm{P}$ were found between the three oils studied, whereas no significant differences were detected for the rest of the elements analyzed. With the exception of $\mathrm{Ca}$ in the 2015 harvest, the levels of these four elements were higher in the $\Delta 7$-STIG sample, followed by the Control and CAMP.

The PO clearly showed lower levels of $\mathrm{Ca}, \mathrm{K}, \mathrm{Mg}$ and $\mathrm{P}$ than their $\mathrm{SO}$ homologues. Specifically, the PO showed P levels between 9 and $36 \mathrm{mg} \mathrm{kg}^{-1}$, whereas the levels ranged from 263 to $585 \mathrm{mg} \mathrm{kg}^{-1}$ in the SO. Levels of $\mathrm{P}$ as high as those of the present work have also been reported by other authors. ${ }^{30,32}$ These results can be attributed to the greater extraction capacity of hexane than of the oil itself, as previously remarked for phytosterols.

As to the minerals of nutritional interest, such as $\mathrm{Cu}, \mathrm{Fe}$ and $\mathrm{Zn}$, no substantial differences were found between the PO and SO, except for Fe in the 2017 harvest, where the SO clearly presented higher levels.

The oils from the 2017 harvest exhibited higher levels of Ca compared to their counterparts in 2015. The same was also observed for $\mathrm{Mg}$ and $\mathrm{P}$, with the exception of the Control SO. Likewise, the Fe concentrations in the SO were also higher in the 2017 harvest, whereas similar results were found between harvests for the PO.

\section{Comparison with the characteristics required in the Codex Alimentarius for seed virgin oils}

The press oils met the definition of seed virgin oil, since they were obtained without modifying the oil by mechanical procedures and by application of heat only after seed conditioning. They can even be considered cold pressed oils, since the seeds were not roasted before extraction. ${ }^{33}$ The color, smell and taste were characteristic of sunflower oil, and free of strange flavors.

The contents of sterols and tocopherols were within the ranges of specifications for sunflower oil (Table 3S). However, except the Control, the oils had special compositions of sterols. Therefore, an adaptation of the regulation would be required to include these new cultivars. 
The oil samples met the quality specifications for volatile matter at $105^{\circ} \mathrm{C}(<0.2 \%)$ and insoluble impurities $(<0.05 \%)$ (data not shown), as well as acidity, which was less than $1 \%$ in all cases.

The greatest difficulties to market these virgin oils were found in the content of trace metals, specifically $\mathrm{Fe}, \mathrm{Cu}, \mathrm{Pb}$ and $\mathrm{As}$ (Table $3 \mathrm{~S}$ ). The contents of $\mathrm{Fe}, \mathrm{Cu}$ and $\mathrm{Pb}$ were close to the limit or exceeded the maximum levels established in the Codex Alimentarius. Arsenic showed rather high levels in $2015(0.7-1.0 \mathrm{mg} / \mathrm{kg})$ compared to the limit established $(\leq 0.1 \mathrm{mg} / \mathrm{kg})$, whereas it was not detected in 2017. In this respect, high levels of heavy metals in oils, such as $\mathrm{Pb}, \mathrm{Ni}, \mathrm{Cd}$ and $\mathrm{Mn}$ have been attributed to their presence in soil and in wastewater used sometimes for agricultural irrigation. ${ }^{8}$

\section{CONCLUSIONS}

Differences in environmental and/or cultivation conditions between harvest seasons may result in substantial differences in the FA composition and the total content of phytosterols in the oils from the three new sunflower seed hybrids studied.

Through rigorous measures and controls to avoid metal-trace contamination from fertilizers and plant-protection products, the PO could be commercialized as edible virgin oils and so be considered a good alternative to their blend with SO, which necessarily have to be refined losing significant amounts of phytosterols and other bioactive components.

\section{ACKNOWLEDGEMENTS}

The authors thank Irene Pérez de la Rosa, Carmen M. Olmo and Visitación Ortega for technical assistance. This work was supported by research project P12-AGR-18371 from Junta de Andalucía and EU FEDER funds. Aída García also thanks Junta de Andalucía for receiving a PhD grant associated to project P12-AGR-18371.

\section{REFERENCES}

1. Zhang T, Liu R, Chang M, Jin Q, Zhang H and Wang X, Health benefits of 4, 4-dimethyl phytosterols: an exploration beyond 4-desmethyl phytosterols. Food Funct 11:93-110 (2020).

2. Velasco L and Ruiz-Méndez MV, Sunflower Oil Minor Constituents, in Sunflower, ed. by Martínez-Force E, Dunford NT and Salas JJ. Am Oil Chem Soc, AOCS Press, Urbana, IL 61802, pp. 297-329 (2015).

3. Fernández-Cuesta A, Jan CC, Fernández-Martínez JM and Velasco L, Variability for seed phytosterols in sunflower germplasm. Crop Sci 54:190-197 (2014). 
4. González Belo R, Velasco L, Nolasco SM and Izquierdo NG, Oil Phytosterol Concentration in Sunflower Presents a Dilution Response with Oil Weight per Grain. J Am Oil Chem Soc 96:1115-1123 (2019).

5. Cicero N, Albergamo A, Salvo A, Bua GD, Bartolomeo G, Mangano V, Rotondo A, di Stefano V, di Bella G and Dugo G, Chemical characterization of a variety of cold-pressed gourmet oils available on the Brazilian market. Food Res Int 109:517-525 (2018).

6. Ruiz-Méndez MV, Velasco J and Márquez-Ruiz G, Recovery of Phytosterols from Refining By-Products of Vegetable Oils, in Phytosterols: Food Sources, Functions and Health Benefits, ed. by Deanna Garner. Nova Science Publishers, New York, USA, pp.12 (2015).

7. CODEX ALIMENTARIUS. Codex standard for named vegetable oils. CODEX STAN 2101999, pp 1-14 (2015).

8. Sahay S, Iqbal S, Inam A, Gupta M and Inam A, Waste water irrigation in the regulation of soil properties, growth determinants, and heavy metal accumulation in different Brassica species. Environ Monit Assess 191:107 (2019).

9. García-González A, Velasco J, Velasco L and Ruiz-Méndez MV, An analytical simplification for faster determination of fatty acid composition and phytosterols in seed oils. Food Anal Methods 11:1234-1242 (2018).

10. Castro CD and Leite RDC, Main aspects of sunflower production in Brazil. OCL - Oilseeds and fats, Crops and Lipids (2018);25: 1-11

11. Grompone M Antonia. Sunflower Oil. Frank D. Gunstone, Vegetable Oils in Food Technology, 2nd Wiley-Blackwell, Pondicherry, India, (2011).137-167.

12. https://doi.org/10.1002/047167849X.bio017.pub2Aguirre MR, Velasco J and Ruiz-Méndez $\mathrm{MV}$, Characterization of sunflower oils obtained separately by pressing and subsequent solvent extraction from a new line of seeds rich in phytosterols and conventional seeds. OCL 21:D605 (2014).

13.Bendini A, Barbieri S, Valli E, Buchecker K, Canavari M and Toschi TG, Quality evaluation of cold pressed sunflower oils by sensory and chemical analysis. Eur J Lipid Sci Technol 113:1375-1384 (2011).

14.Lajara JR, Diaz U and Quidiello RD, Definite influence of location and climatic conditions on the fatty acid composition of sunflower seed oil. J Am Oil Chem Soc 67:618-623 (1990).

15.Roche J, Bouniols A, Mouloungui Z, Barranco T and Cerny M, Management of environmental crop conditions to produce useful sunflower oil components. Eur J Lipid Sci Technol 108:287-297 (2006).

16. Roche J, Mouloungui Z, Cerny M and Merah O, Fatty acid and phytosterol accumulation during seed development in three oilseed species. Int J Food Sc Technol 51:1820-1826 (2016). 
17. Roche J, Mouloungui Z, Cerny M and Merah O, Effect of sowing dates on fatty acids and phytosterols patterns of Carthamus tinctorius L. Appl Sci 9:2839 (2019).

18.Fernández-Cuesta A, Nabloussi A, Fernández-Martínez JM and Velasco L, Tocopherols and phytosterols in sunflower seeds for the human food market. Grasas Aceites 63:321-327 (2012).

19.Li TS, Beveridge TH and Drover JC, Phytosterol content of sea buckthorn (Hippophae rhamnoides L.) seed oil: Extraction and identification. Food Chem 101:1633-1639 (2007).

20. Schaller H, The role of sterols in plant growth and development. Prog Lipid Res 42:163-175 (2003).

21. Roche J, Alignan M, Bouniols A, Cerny M, Mouloungui Z and Merah O, Sterol concentration and distribution in sunflower seeds (Helianthus annuus L.) during seed development. Food Chem 119:1451-1456 (2010).

22. Vlahakis C and Hazebroek J, Phytosterol accumulation in canola, sunflower, and soybean oils: effects of genetics, planting location, and temperature. J Am Oil Chem Soc 77:49-53 (2000).

23. Yamaya A, Endo Y, Fujimoto K and Kitamura K, Effects of genetic variability and planting location on the phytosterol content and composition in soybean seeds. Food Chem 102:10711075 (2007).

24. Hamama AA, Bhardwaj HL and Starner DE, Genotype and growing location effects on phytosterols in canola oil. J Am Oil Chem Soc 80:1121-1126 (2003).

25. Anastasi U, Santonoceto C, Giuffrè AM, Sortino O, Gresta F and Abbate V, Yield performance and grain lipid composition of standard and oleic sunflower as affected by water supply. Field Crops Res 119:145-153 (2010).

26. Ayerdi Gotor A, Berger M, Labalette F, Centis S, Daydé J and Calmon A, Variability and relationships between fatty acids, tocopherols and phytosterols content in sunflower cultivars (Helianthus annuus) from a three years multi-local study. Int J Exp Bot 84:14-25 (2015).

27. Nolasco SM, Aguirrezábal LAN and Crapiste GH, Tocopherol oil concentration in fieldgrown sunflower is accounted for by oil weight per seed. J Am Oil Chem Soc 81:1045-1051 (2004).

28. Almonor GO, Fenner GP and Wilson RF, Temperature effects on tocopherol composition in soybeans with genetically improved oil quality. J Am Oil Chem Soc 75:591-596 (1998).

29.Britz SJ and Kremer DF, Warm temperatures or drought during seed maturation increase free $\alpha$-tocopherol in seeds of soybean (Glycine max [L.] Merr.). J Agric Food Chem 50:6058-6063 (2002).

30.Lamas DL, Crapiste GH and Constenla DT, Changes in quality and composition of sunflower oil during enzymatic degumming process. Food Sci Technol 58:71-76 (2014). 
31. Ansari R, Kazi TG, Jamali MK, Arain MB, Wagan MD, Jalbani N, Afridi HI and Shah AQ, Variation in accumulation of heavy metals in different verities of sunflower seed oil with the aid of multivariate technique. Food Chem 115:318-323 (2009).

32.Lamas DL, Constenla DT and Raab D, Effect of degumming process on physicochemical properties of sunflower oil. Biocatal Agricul Biotechnol 6:138-143 (2016).

33. Matthäus B and Spener F, What we know and what we should know about virgin oils - a general introduction. Eur J Lipid Sci Technol 110:597-601 (2008). 


\section{FIGURE CAPTIONS}

Figure 1.- Temperatures and rainfall during the growing cycle of seeds. Solar radiation was 23.30 and $27.45 \mathrm{MJ} \mathrm{m}^{-2}$ day $^{-1}$ in 2015 and 2017, respectively. 
Table 1. Characteristics of the seeds and yield values for the oil extraction processes.

\begin{tabular}{|c|c|c|c|c|c|c|}
\hline & \multicolumn{2}{|c|}{ Control } & \multicolumn{2}{|c|}{ CAMP } & \multicolumn{2}{|c|}{$\Delta 7-$ STIG } \\
\hline & 2015 & 2017 & 2015 & 2017 & 2015 & 2017 \\
\hline Moisture $\left(\mathrm{g} \mathrm{kg}^{-1}\right)$ & $67 \pm 1.5 \mathrm{bC}$ & $55 \pm 1.8 \mathrm{aC}$ & $62 \pm 1.3 \mathrm{bB}$ & $51 \pm 1.8 \mathrm{aB}$ & $45 \pm 1.2 \mathrm{aA}$ & $46 \pm 1.7 \mathrm{aA}$ \\
\hline Fat Content ( $\left.\mathrm{g} \mathrm{kg}^{-1}\right)$ & $327 \pm 8 \mathrm{aA}$ & $375 \pm 4 \mathrm{bA}$ & $351 \pm 8 \mathrm{aA}$ & $326 \pm 2 b A$ & $420 \pm 1 \mathrm{aB}$ & $376 \pm 3 b B$ \\
\hline \multicolumn{7}{|l|}{ Oil yield ( $\left.\mathrm{g} \mathrm{kg}^{-1}\right)$} \\
\hline Press & $213 \pm 11 \mathrm{aA}$ & $247 \pm 12 \mathrm{aA}$ & $268 \pm 13 \mathrm{aB}$ & $245 \pm 12 \mathrm{aB}$ & $312 \pm 16 \mathrm{aC}$ & $282 \pm 14 \mathrm{aC}$ \\
\hline Solvent $\dagger$ & $164 \pm 16 \mathrm{aB}$ & $148 \pm 15 \mathrm{aB}$ & $141 \pm 14 \mathrm{aA}$ & $123 \pm 12 \mathrm{aA}$ & $182 \pm 18 b B$ & $148 \pm 15 \mathrm{aB}$ \\
\hline Meal oil $\ddagger\left(\mathrm{g} \mathrm{kg}^{-1}\right)$ & $1.7 \pm 0.5 \mathrm{aAB}$ & $2.4 \pm 0.2 \mathrm{aAB}$ & $2.0 \pm 0.1 \mathrm{aA}$ & $1.2 \pm 0.04 \mathrm{aA}$ & $2.4 \pm 0.7 \mathrm{aB}$ & $3.0 \pm 0.9 \mathrm{aB}$ \\
\hline
\end{tabular}

$\dagger$ Values expressed on pellets. $\$$ Residual oil in meal. The results are expressed as mean values \pm standard deviation (n=3). Different lowercase letters show significant differences between harvests (Student's t-test) and different capital letters indicate significant differences between seed samples (Tukey's test) $(p<0.05)$. 
Table 2.- Main fatty acid composition (\%) of the oils.

\begin{tabular}{|c|c|c|c|c|c|c|c|c|c|c|}
\hline & & \multicolumn{3}{|c|}{ Control } & \multicolumn{3}{|c|}{ CAMP } & \multicolumn{3}{|c|}{$\Delta 7-$ STIG } \\
\hline & & Total $\dagger$ & Press & Solvent & Total $\dagger$ & Press & Solvent & Total $\uparrow$ & Press & Solvent \\
\hline \multicolumn{11}{|l|}{2015} \\
\hline & C16:0 & $7.4 \pm 0.03 \mathrm{aB}$ & $7.3 \pm 0.05 \mathrm{aB}$ & $7.7 \pm 0.05 \mathrm{bB}$ & $7.0 \pm 0.07 \mathrm{aB}$ & $7.0 \pm 0.22 \mathrm{aB}$ & $7.3 \pm 0.29 \mathrm{aB}$ & $5.9 \pm 0.10 \mathrm{aA}$ & $6.0 \pm 0.04 \mathrm{aA}$ & $6.4 \pm 0.013 \mathrm{bA}$ \\
\hline & C16:1 & $0.2 \pm 0.01 \mathrm{~A}$ & nd & nd & nd & nd & nd & nd & nd & nd \\
\hline & C18:0 & $4.3 \pm 0.04 \mathrm{aB}$ & $4.3 \pm 0.02 \mathrm{aB}$ & $4.3 \pm 0.01 \mathrm{aB}$ & $2.5 \pm 0.06 \mathrm{aA}$ & $2.5 \pm 0.16 \mathrm{aA}$ & $2.6 \pm 0.15 \mathrm{aA}$ & $3.9 \pm 0.07 \mathrm{aA}$ & $3.9 \pm 0.03 \mathrm{abA}$ & $4.0 \pm 0.03 \mathrm{bA}$ \\
\hline & C18:1 & $35.2 \pm 0.20 \mathrm{bB}$ & $35.3 \pm 0.08 \mathrm{bB}$ & $34.3 \pm 0.08 \mathrm{aB}$ & $34.5 \pm 0.12 \mathrm{aB}$ & $34.4 \pm 1.40 \mathrm{aB}$ & $33.7 \pm 1.41 \mathrm{aB}$ & $40.8 \pm 0.35 b B$ & $39.2 \pm 0.58 \mathrm{abB}$ & $38.3 \pm 0.73 \mathrm{aB}$ \\
\hline & $\mathrm{C} 18: 2$ & $51.4 \pm 0.21 \mathrm{aA}$ & $51.8 \pm 0.13 \mathrm{bA}$ & $52.4 \pm 0.04 \mathrm{cA}$ & $54.8 \pm 0.21 \mathrm{aA}$ & $55.0 \pm 1.33 \mathrm{aA}$ & $55.5 \pm 1.29 \mathrm{aA}$ & $47.9 \pm 0.39 \mathrm{aA}$ & $49.6 \pm 0.58 \mathrm{abA}$ & $49.9 \pm 0.65 \mathrm{bA}$ \\
\hline & $\mathrm{C} 20: 0$ & $0.4 \pm 0.02 \mathrm{aB}$ & $0.4 \pm 0.01 \mathrm{aB}$ & $0.4 \pm 0.02 \mathrm{aB}$ & $0.2 \pm 0.03 \mathrm{aA}$ & $0.2 \pm 0.02 \mathrm{aA}$ & $0.2 \pm 0.01 \mathrm{aA}$ & $0.3 \pm 0.03 \mathrm{aA}$ & $0.3 \pm 0.01 \mathrm{abA}$ & $0.4 \pm 0.02 \mathrm{bA}$ \\
\hline & C18:3 & $0.2 \pm 0.01$ & nd & nd & $0.2 \pm 0.01$ & nd & nd & $0.2 \pm 0.02$ & nd & nd \\
\hline & C20:1 & nd & nd & nd & nd & nd & nd & nd & nd & nd \\
\hline & $\mathrm{C} 22: 0$ & $0.7 \pm 0.02 \mathrm{aB}$ & $0.7 \pm 0.01 \mathrm{aB}$ & $0.7 \pm 0.02 \mathrm{aB}$ & $0.5 \pm 0.03 \mathrm{aA}$ & $0.6 \pm 0.03 \mathrm{aA}$ & $0.5 \pm 0.01 \mathrm{aA}$ & $0.7 \pm 0.08 \mathrm{aB}$ & $0.7 \pm 0.02 \mathrm{aB}$ & $0.7 \pm 0.02 \mathrm{aB}$ \\
\hline & $\mathrm{C} 24: 0$ & $0.3 \pm 0.02 \mathrm{aA}$ & $0.3 \pm 0.02 \mathrm{aA}$ & $0.3 \pm 0.01 \mathrm{aA}$ & $0.2 \pm 0.01 \mathrm{a}$ & $0.3 \pm 0.02 \mathrm{bB}$ & $0.2 \pm 0.01 \mathrm{aA}$ & $0.3 \pm 0.03 \mathrm{aA}$ & $0.3 \pm 0.01 \mathrm{aA}$ & $0.4 \pm 0.02 \mathrm{bA}$ \\
\hline \multicolumn{11}{|l|}{2017} \\
\hline & C16:0 & $6.9 \pm 0.06 \mathrm{aA}$ & $7.0 \pm 0.01 \mathrm{aA}$ & $7.3 \pm 0.02 \mathrm{bA}$ & $6.6 \pm 0.11 \mathrm{aA}$ & $6.5 \pm 0.01 \mathrm{aA}$ & $6.8 \pm 0.03 \mathrm{bA}$ & $7.1 \pm 0.15 \mathrm{aB}$ & $7.1 \pm 0.01 \mathrm{aB}$ & $7.4 \pm 0.00 \mathrm{bB}$ \\
\hline & C16:1 & $0.2 \pm 0.00 \mathrm{aA}$ & $0.2 \pm 0.00 \mathrm{a}$ & $0.2 \pm 0.00 \mathrm{a}$ & nd & nd & nd & nd & $0.1 \pm 0.00 \mathrm{a}$ & $0.1 \pm 0.00 \mathrm{a}$ \\
\hline & $\mathrm{C} 18: 0$ & $3.6 \pm 0.01 \mathrm{aA}$ & $3.6 \pm 0.01 \mathrm{aA}$ & $3.6 \pm 0.01 \mathrm{aA}$ & $3.0 \pm 0.05 \mathrm{aB}$ & $3.0 \pm 0.01 \mathrm{aB}$ & $3.2 \pm 0.01 \mathrm{bB}$ & $4.0 \pm 0.02 \mathrm{aB}$ & $4.1 \pm 0.03 \mathrm{bB}$ & $4.1 \pm 0.01 \mathrm{bB}$ \\
\hline & C18:1 & $30.8 \pm 0.08 \mathrm{cA}$ & $30.0 \pm 0.02 \mathrm{bA}$ & $29.0 \pm 0.03 \mathrm{aA}$ & $31.0 \pm 0.17 \mathrm{cA}$ & $30.0 \pm 0.08 \mathrm{bA}$ & $29.6 \pm 0.04 \mathrm{aA}$ & $23.9 \pm 0.15 \mathrm{bA}$ & $23.8 \pm 0.02 \mathrm{bA}$ & $23.6 \pm 0.02 \mathrm{aA}$ \\
\hline & C18:2 & $57.2 \pm 0.10 \mathrm{aB}$ & $57.9 \pm 0.05 \mathrm{bB}$ & $58.5 \pm 0.06 \mathrm{cB}$ & $58.7 \pm 0.23 \mathrm{aB}$ & $59.5 \pm 0.09 \mathrm{bB}$ & $59.3 \pm 0.07 \mathrm{bB}$ & $64.0 \pm 0.10 \mathrm{cB}$ & $63.6 \pm 0.02 \mathrm{bB}$ & $63.3 \pm 0.02 \mathrm{aB}$ \\
\hline & C20:0 & $0.3 \pm 0.00 \mathrm{aA}$ & $0.3 \pm 0.00 \mathrm{aA}$ & $0.3 \pm 0.00 \mathrm{aA}$ & $0.2 \pm 0.01 \mathrm{aA}$ & $0.3 \pm 0.04 \mathrm{bA}$ & $0.2 \pm 0.00 \mathrm{aA}$ & $0.3 \pm 0.02 \mathrm{aA}$ & $0.3 \pm 0.00 \mathrm{aA}$ & $0.3 \pm 0.00 \mathrm{aA}$ \\
\hline & C18:3 & nd & $0.1 \pm 0.00 \mathrm{a}$ & $0.1 \pm 0.00 \mathrm{a}$ & nd & nd & nd & nd & $0.1 \pm 0.00 \mathrm{a}$ & $0.1 \pm 0.00 \mathrm{a}$ \\
\hline & $\mathrm{C} 20: 1$ & $0.2 \pm 0.00 \mathrm{a}$ & $0.2 \pm 0.00 \mathrm{a}$ & $0.2 \pm 0.00 \mathrm{a}$ & nd & $0.1 \pm 0.02 \mathrm{a}$ & $0.2 \pm 0.00 \mathrm{~b}$ & nd & $0.2 \pm 0.00 \mathrm{~b}$ & $0.2 \pm 0.00 \mathrm{~b}$ \\
\hline & $\mathrm{C} 22: 0$ & $0.6 \pm 0.00 \mathrm{aA}$ & $0.6 \pm 0.00 \mathrm{aA}$ & $0.6 \pm 0.01 \mathrm{aA}$ & $0.5 \pm 0.02 \mathrm{bB}$ & $0.4 \pm 0.05 \mathrm{aB}$ & $0.5 \pm 0.01 \mathrm{bB}$ & $0.5 \pm 0.02 \mathrm{aA}$ & $0.6 \pm 0.01 \mathrm{bA}$ & $0.6 \pm 0.00 \mathrm{bA}$ \\
\hline & $\mathrm{C} 24: 0$ & $0.3 \pm 0.00 \mathrm{aA}$ & $0.3 \pm 0.00 \mathrm{aA}$ & $0.3 \pm 0.00 \mathrm{aA}$ & nd & $0.1 \pm 0.02 \mathrm{aA}$ & $0.2 \pm 0.00 \mathrm{bA}$ & $0.3 \pm 0.03 \mathrm{aA}$ & $0.3 \pm 0.00 \mathrm{aA}$ & $0.3 \pm 0.00 \mathrm{aA}$ \\
\hline
\end{tabular}

$\uparrow$ Total oil obtained by Soxhlet extraction from whole seeds. nd, not detected. The results are expressed as mean values \pm standard deviation ( $\mathrm{n}=4$ ). Different lower case letters show significant differences between the oils obtained from a given seed cultivar for each harvest separately (Tukey's test/Games-Howell) ( $p<0.05$ ). Different capital letters denote significant differences between harvests (student's $t$ test) $(p<0.05)$. 
Table 3.- Composition and total concentration of major phytosterols in the oils.

\begin{tabular}{|c|c|c|c|c|c|c|c|c|c|c|}
\hline & & \multicolumn{3}{|c|}{ Control } & \multicolumn{3}{|c|}{ CAMP } & \multicolumn{3}{|c|}{$\Delta 7-$ STIG } \\
\hline & & Total $\dagger$ & Press & Solvent & Total $\dagger$ & Press & Solvent & Total $\dagger$ & Press & Solvent \\
\hline \multicolumn{11}{|l|}{2015} \\
\hline & Composition (\%) & & & & & & & & & \\
\hline & Campesterol & $7.6 \pm 0.10 \mathrm{aB}$ & $7.8 \pm 0.52 \mathrm{aB}$ & $8.4 \pm 0.15 \mathrm{bB}$ & $29.0 \pm 1.37 \mathrm{cB}$ & $31.2 \pm 1.10 \mathrm{bB}$ & $26.7 \pm 0.62 \mathrm{aB}$ & $6.8 \pm 0.15 \mathrm{aA}$ & $6.9 \pm 0.26 \mathrm{aB}$ & $8.0 \pm 0.37 \mathrm{bA}$ \\
\hline & Stigmasterol & $7.4 \pm 0.35 \mathrm{bA}$ & $6.7 \pm 0.11 \mathrm{aA}$ & $10.4 \pm 0.32 \mathrm{cA}$ & $7.4 \pm 0.19 \mathrm{aA}$ & $7.5 \pm 0.40 \mathrm{aA}$ & $9.7 \pm 0.24 \mathrm{bA}$ & $9.2 \pm 0.09 \mathrm{aA}$ & $8.9 \pm 0.26 \mathrm{aA}$ & $10.5 \pm 0.26 \mathrm{bA}$ \\
\hline & $\beta$-Sitosterol & $63.6 \pm 0.47 \mathrm{abB}$ & $65.2 \pm 0.87 \mathrm{bB}$ & $62.6 \pm 1.14 \mathrm{aB}$ & $48.8 \pm 0.53 \mathrm{aA}$ & $49.7 \pm 1.18 \mathrm{abB}$ & $50.9 \pm 0.37 \mathrm{bA}$ & $49.5 \pm 0.65 \mathrm{aA}$ & $52.9 \pm 0.96 \mathrm{bB}$ & $53.5 \pm 0.73 \mathrm{bB}$ \\
\hline & $\Delta 5$-Avenasterol & $2.9 \pm 0.28 \mathrm{~B}$ & nd & nd & $3.5 \pm 0.51 \mathrm{~A}$ & nd & nd & $3.9 \pm 0.20 \mathrm{~B}$ & nd & nd \\
\hline & $\Delta 7$-Stigmastenol & $15.0 \pm 0.90 \mathrm{abA}$ & $16.6 \pm 0.44 \mathrm{bA}$ & $14.6 \pm 0.75 \mathrm{aA}$ & $7.3 \pm 0.72 \mathrm{aB}$ & $7.2 \pm 0.59 \mathrm{aB}$ & $8.3 \pm 0.91 \mathrm{aB}$ & $25.8 \pm 0.65 \mathrm{abA}$ & $26.8 \pm 0.72 \mathrm{bA}$ & $24.0 \pm 1.04 \mathrm{aA}$ \\
\hline & $\Delta 7$-Avenasterol & $3.6 \pm 0.06 \mathrm{aA}$ & $3.7 \pm 0.05 \mathrm{aA}$ & $4.0 \pm 0.14 \mathrm{bA}$ & $3.9 \pm 0.08 \mathrm{aA}$ & $4.4 \pm 0.18 \mathrm{bA}$ & $4.4 \pm 0.22 \mathrm{bB}$ & $4.6 \pm 0.20 \mathrm{bB}$ & $4.4 \pm 0.18 \mathrm{abA}$ & $4.0 \pm 0.24 \mathrm{aA}$ \\
\hline & Total (mg kg $\left.{ }^{-1}\right)$ & $3644 \pm 230 \mathrm{bA}$ & $3246 \pm 35 \mathrm{aA}$ & $5065 \pm 10 \mathrm{cA}$ & $4008 \pm 454 \mathrm{bA}$ & $2839 \pm 109 \mathrm{aA}$ & $4849 \pm 439 \mathrm{cA}$ & $4415 \pm 341 \mathrm{aA}$ & $4290 \pm 232 \mathrm{aA}$ & $5754 \pm 388 \mathrm{bA}$ \\
\hline \multicolumn{11}{|l|}{2017} \\
\hline & Campesterol & $6.3 \pm 0.13 \mathrm{aA}$ & $6.2 \pm 0.06 \mathrm{aA}$ & $7.3 \pm 0.15 \mathrm{bA}$ & $26.7 \pm 0.33 \mathrm{bA}$ & $28.2 \pm 0.1 \mathrm{cA}$ & $23.4 \pm 0.19 \mathrm{aA}$ & $7.0 \pm 0.04 \mathrm{bB}$ & $6.2 \pm 0.06 \mathrm{aA}$ & $8.3 \pm 0.04 \mathrm{cA}$ \\
\hline & Stigmasterol & $8.9 \pm 0.3 \mathrm{bB}$ & $7.8 \pm 0.08 \mathrm{aB}$ & $11.4 \pm 0.14 \mathrm{cB}$ & $9.0 \pm 0.13 \mathrm{aB}$ & $8.9 \pm 0.29 \mathrm{aB}$ & $11.0 \pm 0.11 \mathrm{bB}$ & $10.9 \pm 0.05 \mathrm{bB}$ & $9.4 \pm 0.19 \mathrm{aB}$ & $12.6 \pm 0.25 \mathrm{cB}$ \\
\hline & $\beta$-Sitosterol & $61.7 \pm 0.98 \mathrm{bA}$ & $61.2 \pm 0.4 \mathrm{bA}$ & $57.9 \pm 0.2 \mathrm{aA}$ & $49.7 \pm 0.17 \mathrm{bB}$ & $47.5 \pm 0.07 \mathrm{aA}$ & $50.9 \pm 0.35 \mathrm{cA}$ & $49.2 \pm 0.14 \mathrm{bA}$ & $46.6 \pm 1.1 \mathrm{aA}$ & $48.1 \pm 0.09 \mathrm{bA}$ \\
\hline & $\Delta 5$-Avenasterol & $1.5 \pm 0.03 \mathrm{aA}$ & $1.6 \pm 0.04 \mathrm{~b}$ & $1.7 \pm 0.04 \mathrm{c}$ & $3.3 \pm 0.04 \mathrm{aA}$ & $3.7 \pm 0.07 \mathrm{~b}$ & $3.3 \pm 0.03 \mathrm{a}$ & $0.9 \pm 0.05 \mathrm{aA}$ & $0.9 \pm 0.03 \mathrm{a}$ & $1.5 \pm 0.05 b$ \\
\hline & $\Delta 7$-Estigmastenol & $17.8 \pm 1.4 \mathrm{aB}$ & $18.8 \pm 0.51 \mathrm{aB}$ & $17.3 \pm 0.46 \mathrm{aB}$ & $7.1 \pm 0.45 \mathrm{aA}$ & $6.7 \pm 0.18 \mathrm{aA}$ & $7.7 \pm 0.64 \mathrm{bA}$ & $27.5 \pm 0.20 \mathrm{bB}$ & $32.5 \pm 1.58 \mathrm{cB}$ & $24.8 \pm 0.48 \mathrm{aA}$ \\
\hline & $\Delta 7$-Avenasterol & $3.8 \pm 0.12 \mathrm{aB}$ & $4.5 \pm 0.1 \mathrm{bB}$ & $4.4 \pm 0.19 \mathrm{bB}$ & $4.1 \pm 0.11 \mathrm{bA}$ & $4.9 \pm 0.12 \mathrm{cB}$ & $3.6 \pm 0.05 \mathrm{aA}$ & $4.4 \pm 0.04 \mathrm{aA}$ & $4.3 \pm 0.28 \mathrm{aA}$ & $4.6 \pm 0.22 \mathrm{aB}$ \\
\hline & Total $\left(\mathrm{mg} \mathrm{kg}^{-1}\right)$ & $5370 \pm 347 \mathrm{bB}$ & $4476 \pm 136 \mathrm{aB}$ & $7272 \pm 343 \mathrm{cB}$ & $4666 \pm 124 \mathrm{aB}$ & $5225 \pm 203 \mathrm{bB}$ & $6678 \pm 387 \mathrm{cB}$ & $7177 \pm 214 \mathrm{bB}$ & $5284 \pm 200 \mathrm{aB}$ & $9249 \pm 669 \mathrm{cB}$ \\
\hline
\end{tabular}

$\uparrow$ Total oil obtained by Soxhlet extraction from whole seeds. nd, not detected. The results are expressed as mean values \pm standard deviation ( $\mathrm{n}=4$ ). Different lower case letters show significant differences between the oils obtained from a given seed cultivar for each harvest separately (Tukey's test/Games-Howell) ( $p<0.05$ ). Different capital letters denote significant differences between harvests (student's $t$ test) $(p<0.05)$. 
Table 4.- Elemental analysis $\left(\mathrm{mg} \mathrm{kg}^{-1}\right)$ of the oils $(\mathrm{n}=2)$.

\begin{tabular}{|c|c|c|c|c|c|c|c|}
\hline & & \multicolumn{2}{|c|}{ Control } & \multicolumn{2}{|c|}{ CAMP } & \multicolumn{2}{|c|}{$\Delta 7-$ STIG } \\
\hline & & Press & Solvent & Press & Solvent & Press & Solvent \\
\hline \multicolumn{8}{|c|}{2015} \\
\hline & As & 0.9 & 1.2 & 1.0 & 0.8 & 0.7 & 1.1 \\
\hline & $\mathrm{Ca}$ & 31.8 & 202.8 & 24.1 & 99.6 & 21.9 & 158.9 \\
\hline & $\mathrm{Cd}$ & nd & nd & 0.1 & nd & nd & nd \\
\hline & $\mathrm{Cu}$ & 0.4 & 0.4 & 0.5 & 0.3 & 0.4 & 0.4 \\
\hline & $\mathrm{Fe}$ & 7.0 & 4.5 & 3.1 & 2.6 & 4.4 & 4.3 \\
\hline & K & 7.6 & 75.6 & 7.2 & 38.9 & 4.8 & 95.0 \\
\hline & $\mathrm{Mg}$ & 6.7 & 134.7 & 5.8 & 60.4 & 4.6 & 107.6 \\
\hline & $\mathrm{Na}$ & 3.0 & 2.5 & 7.6 & 2.9 & nd & 11.6 \\
\hline & $\mathrm{P}$ & 11.7 & 511.5 & 9.3 & 262.8 & 11.9 & 513.7 \\
\hline & $\mathrm{Pb}$ & nd & 0.2 & 0.2 & 0.1 & 0.1 & nd \\
\hline & S & 11.4 & 11.5 & 11.6 & 13.4 & 7.3 & 19.0 \\
\hline & $\mathrm{Sr}$ & 0.1 & 0.4 & 0.1 & 0.2 & 0.1 & 0.3 \\
\hline & $\mathrm{V}$ & 0.1 & 0.2 & 0.1 & 0.1 & 0.1 & 0.1 \\
\hline & $\mathrm{Zn}$ & 4.7 & 1.9 & 0.8 & 1.9 & 1.4 & 2.9 \\
\hline \multicolumn{8}{|c|}{2017} \\
\hline & As & nd & nd & nd & nd & nd & nd \\
\hline & $\mathrm{Ca}$ & 78.5 & 217.0 & 58.6 & 173.6 & 106.9 & 305.4 \\
\hline & $\mathrm{Cd}$ & nd & nd & 0.1 & nd & nd & 0.1 \\
\hline & $\mathrm{Cu}$ & 1.1 & 0.5 & 0.2 & 0.5 & 0.3 & 1.1 \\
\hline & $\mathrm{Fe}$ & 6.0 & 22.7 & 4.6 & 23.5 & 5.8 & 32.0 \\
\hline & K & 6.7 & 61.0 & 7.3 & 31.0 & 6.4 & 95.4 \\
\hline & $\mathrm{Mg}$ & 11.6 & 114.1 & 6.3 & 63.7 & 14.4 & 158.2 \\
\hline & $\mathrm{Na}$ & 4.0 & 6.6 & 2.9 & 9.8 & 6.1 & 9.2 \\
\hline & $\mathrm{P}$ & 27.3 & 404.2 & 15.4 & 295.6 & 36.4 & 585.1 \\
\hline & $\mathrm{Pb}$ & nd & 0.2 & 0.2 & 0.2 & 0.4 & 0.4 \\
\hline & $S$ & 13.0 & 17.9 & 6.6 & 12.3 & 14.3 & 15.0 \\
\hline & $\mathrm{Zn}$ & 1.0 & 2.5 & 0.6 & 1.5 & 1.5 & 4.6 \\
\hline
\end{tabular}

Coefficient of variation $\leq 7 \%$ 


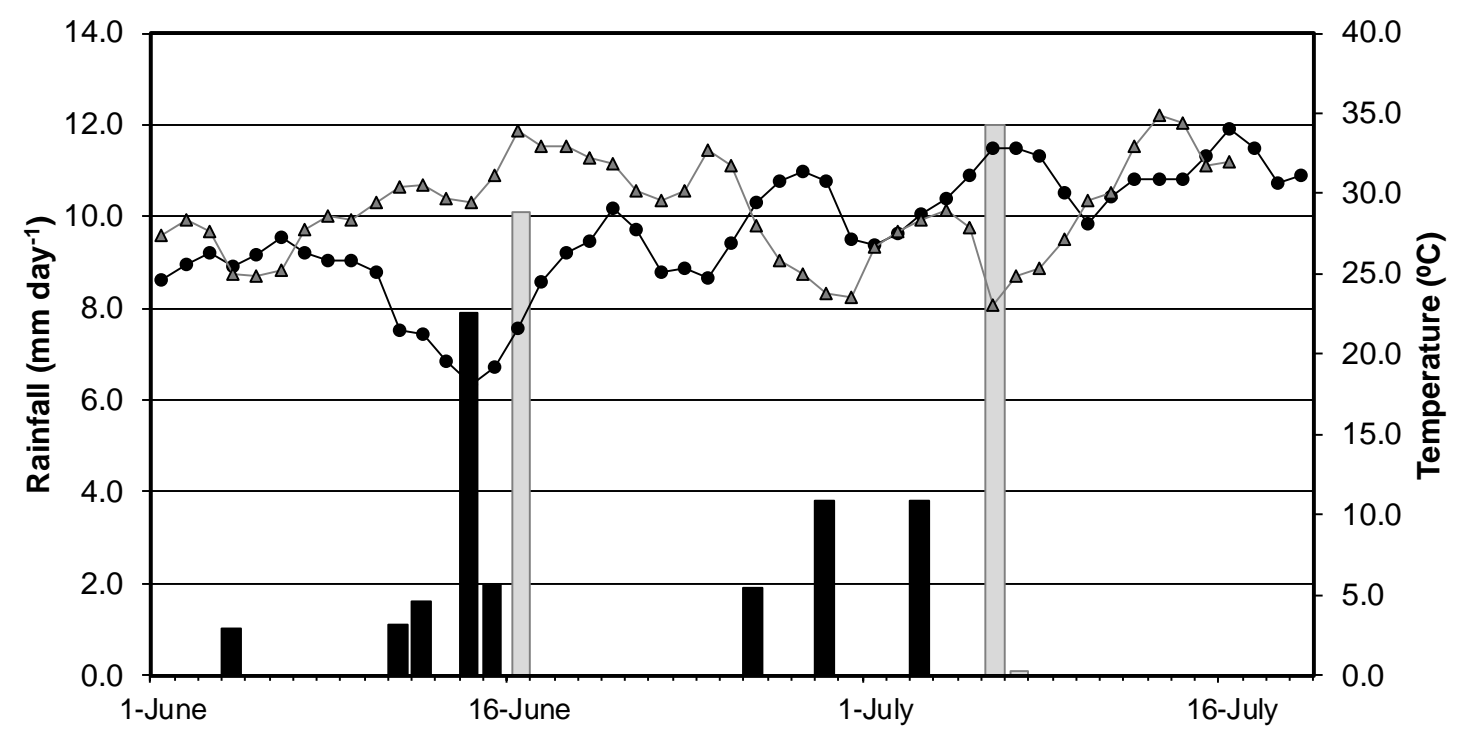

Rainfall $2015 \square$ Rainfall $2017 \rightarrow$-Medium temperature $2015 \rightarrow$ Medium temperature 2017

Figure 1 
Table 1S.- Acidity (\% on oleic acid) of the oils.

\begin{tabular}{|c|c|c|c|c|c|c|}
\hline & \multicolumn{2}{|c|}{ Control } & \multicolumn{2}{|c|}{ CAMP } & \multicolumn{2}{|c|}{$\Delta 7-S T I G$} \\
\hline & 2015 & 2017 & 2015 & 2017 & 2015 & 2017 \\
\hline Press & $0.15 \mathrm{aA}$ & $1.00 \mathrm{aB}$ & $0.26 \mathrm{aA}$ & $0.99 \mathrm{aB}$ & $0.10 \mathrm{aA}$ & $1.00 \mathrm{aB}$ \\
\hline Solvent & $0.71 \mathrm{bA}$ & $1.42 \mathrm{bB}$ & $0.84 \mathrm{bA}$ & $1.64 \mathrm{bB}$ & $0.59 \mathrm{bA}$ & $1.55 \mathrm{bB}$ \\
\hline
\end{tabular}

The results are expressed as mean values $(n=2)$. The variation coefficient was $\leq 5 \%$. Different lower case letters denote significant differences $(p<0.05)$ between extraction methods (MannWhitney $U$ test) and different capital letters between harvests (Mann-Whitney U test). 
Table 2S.- Total tocopherol content $\left(\mathrm{mg} \mathrm{kg}^{-1}\right)$ in the oils.

\begin{tabular}{|c|c|c|c|c|c|c|}
\hline & \multicolumn{2}{|c|}{ Control } & \multicolumn{2}{|c|}{ CAMP } & \multicolumn{2}{|c|}{$\Delta 7-$ STIG } \\
\hline & Press & Solvent & Press & Solvent & Press & Solvent \\
\hline 2015 & $524 \mathrm{aA}$ & $492 \mathrm{aA}$ & $870 \mathrm{aA}$ & $1025 \mathrm{aA}$ & $777 \mathrm{aA}$ & $764 \mathrm{aA}$ \\
\hline 2017 & $515 \mathrm{aA}$ & $517 \mathrm{aA}$ & $881 \mathrm{aA}$ & $912 \mathrm{aA}$ & $722 \mathrm{aA}$ & $784 \mathrm{aA}$ \\
\hline
\end{tabular}

The results are expressed as mean values $(n=2)$. The variation coefficient was $\leq 5 \%$. Different lower case letters denote significant differences $(p<0.05)$ between extraction methods (MannWhitney $U$ test) and different capital letters between harvests (Mann-Whitney U test). 
Table 3S.- Main compositional characteristics and quality parameters for virgin sunflower oils according to Codex Alimentarius and average values of the two harvests found in the press oils.

\begin{tabular}{|c|c|c|c|c|c|}
\hline & \multicolumn{2}{|c|}{ CODEX STAN 210-1999 } & \multicolumn{3}{|c|}{ Samples } \\
\hline & Sunflower & High Oleic & Control & CAMP & $\Delta 7$-STIG \\
\hline \multicolumn{6}{|l|}{ Fatty Acids (\%) } \\
\hline C16:0 & $5.0-7.6$ & $2.6-5.0$ & $7.2 \pm 0.2$ & $6.8 \pm 0.4$ & $6.6 \pm 0.8$ \\
\hline C16:1 & nd- 0.3 & nd-0.1 & $0.1 \pm 0.1$ & nd & $0.1 \pm 0.1$ \\
\hline C18:0 & $2.3-4.0$ & $2.0-4.0$ & $4.0 \pm 0.5$ & $2.8 \pm 0.4$ & $4.0 \pm 0.1$ \\
\hline C18:1 & $14.0-39.4$ & $75.0-90.7$ & $32.5 \pm 3.8$ & $32.2 \pm 3.1$ & $31.1 \pm 10.9$ \\
\hline C18:2 & $48.3-74.0$ & $2.1-17.0$ & $54.8 \pm 4.4$ & $57.3 \pm 3.2$ & $56.6 \pm 9.9$ \\
\hline C18:3 & nd- 0.3 & nd- 0.3 & $0.03 \pm 0.04$ & nd & $0.1 \pm 0.1$ \\
\hline C20:0 & $0.1-0.5$ & $0.2-0.5$ & $0.4 \pm 0.1$ & $0.3 \pm 0.0$ & $0.3 \pm 0.0$ \\
\hline C20:1 & nd- 0.3 & $0.1-0.5$ & $0.1 \pm 0.1$ & $0.1 \pm 0.1$ & $0.1 \pm 0.1$ \\
\hline $\mathrm{C} 22: 0$ & $0.3-1.5$ & $0.5-1.6$ & $0.7 \pm 0.1$ & $0.5 \pm 0.1$ & $0.7 \pm 0.1$ \\
\hline $\mathrm{C} 24: 0$ & nd- 0.5 & nd- -0.5 & $0.3 \pm 0.0$ & $0.2 \pm 0.1$ & $0.3 \pm 0.0$ \\
\hline \multicolumn{6}{|l|}{ Sterols (\%) } \\
\hline Campesterol & $6.5-13.0$ & $5.0-13.0$ & $7.0 \pm 1.2$ & $29.7 \pm 2.1$ & $6.5 \pm 0.5$ \\
\hline Stigmasterol & $6.0-13.0$ & $4.5-13.0$ & $7.2 \pm 0.8$ & $8.2 \pm 1.0$ & $9.1 \pm 0.4$ \\
\hline$\beta$-Sitosterol & $50-70$ & $42.0-70$ & $63.2 \pm 2.8$ & $47.6 \pm 1.5$ & $49.7 \pm 4.4$ \\
\hline$\Delta 5$-Avenasterol & nd-6.9 & $1.5-6.9$ & $0.8 \pm 1.2$ & $1.8 \pm 2.6$ & $0.4 \pm 0.7$ \\
\hline$\Delta 7$-Stigmastenol & $6.5-24.0$ & $6.5-24.0$ & $17.7 \pm 1.6$ & $6.9 \pm 0.3$ & $29.6 \pm 4.0$ \\
\hline$\Delta 7$-Avenasterol & $3.0-7.5$ & nd-9.0 & $4.1 \pm 0.5$ & $4.6 \pm 0.4$ & $4.3 \pm 0.1$ \\
\hline $\begin{array}{l}\text { Total Sterols } \\
\quad\left(\mathrm{mg} \mathrm{kg}^{-1}\right)\end{array}$ & $2400-5000$ & $1700-5200$ & $3861 \pm 870$ & $4032 \pm 1687$ & $4787 \pm 702$ \\
\hline $\begin{array}{r}\text { Tocopherols } \\
\left(\mathrm{mg} \mathrm{kg}^{-1}\right)\end{array}$ & $450-1120$ & $450-1120$ & $520 \pm 6$ & $876 \pm 8$ & $750 \pm 39$ \\
\hline \multicolumn{6}{|c|}{ Quality Characteristics } \\
\hline $\begin{array}{l}\text { Acidity } \\
\text { (\% on oleic) }\end{array}$ & $\leq 2$ & $\leq 2$ & $\leq 1$ & $\leq 1$ & $\leq 1$ \\
\hline $\mathrm{Fe}\left(\mathrm{mg} \mathrm{kg}^{-1}\right)$ & $\leq 5$ & $\leq 5$ & $\leq 7$ & $\leq 4,6$ & $\leq 5,8$ \\
\hline $\mathrm{Cu}\left(\mathrm{mg} \mathrm{kg}^{-1}\right)$ & $\leq 0.4$ & $\leq 0.4$ & $\leq 1,1$ & $\leq 0,5$ & $\leq 0,4$ \\
\hline $\mathrm{Pb}\left(\mathrm{mg} \mathrm{kg}^{-1}\right)$ & $\leq 0.1$ & $\leq 0.1$ & nd & $\leq 0,2$ & $\leq 0,4$ \\
\hline As $\left(\mathrm{mg} \mathrm{kg}^{-1}\right)$ & $\leq 0.1$ & $\leq 0.1$ & n.d. $/ \leq 0,9$ & n.d. $/ \leq 1.0$ & n.d. $I \leq 0,7$ \\
\hline
\end{tabular}

